\title{
EFFECT OF ORGANIC SUBSTANCES ON THE EFFICIENCY OF Fe(II) TO Fe(III) OXIDATION AND REMOVAL OF IRON COMPOUNDS FROM GROUNDWATER IN THE SEDIMENTATION PROCESS
}

\author{
Izabela KRUPIŃSKA ${ }^{1}$ \\ University of Zielona Góra, Zielona Góra, Poland
}

\begin{abstract}
One of the problems with iron removal from groundwater is organic matter. The article presents the experiments involved groundwater samples with a high concentration of total iron - amounting to $7.20 \mathrm{mgFe} / \mathrm{dm}^{3}$ and an increased amount of organic substances (TOC from 5.50 to $7.50 \mathrm{mgC} / \mathrm{dm}^{3}$ ). The water samples examined differed in terms of the value of the ratio of the TOC concentration and the concentration of total iron (D). It was concluded that with increase in the coexistence ratio of organic substances and total iron in water $\left(\mathrm{D}=[\mathrm{TOC}] /\left[\mathrm{Fe}_{\text {tot }}\right]\right.$ ), efficiency of $\mathrm{Fe}(\mathrm{II})$ to $\mathrm{Fe}(\mathrm{III})$ oxidization with dissolved oxygen decreased, while the oxidation time was increasing. This rule was not demonstrated for potassium manganate (VII) when used as an oxidizing agent. The application of potassium manganate (VII) for oxidation of $\mathrm{Fe}(\mathrm{II})$ ions produced the better results in terms of total iron concentration reduction in the sedimentation process than the oxidation with dissolved oxygen.
\end{abstract}

Keywords: groundwater treatment, organic substances, aeration, potassium manganate (VII), $\mathrm{Fe}(\mathrm{II})$ oxidation, removal of iron

\footnotetext{
1 Corresponding author: University of Zielona Gora, Faculty of Civil and Environmental Engineering Institute of Environmental Engineering, Szafrana st 15, 65-246 Zielona Góra, Poland, e-mail: i.krupinska@iis.uz.zgora.pl tel.+48683282560
} 


\section{INTRODUCTION}

The presence of iron in the drinking water supply is not harmful to human health, however it is undesirable. Bad taste, discoloration, staining, deposition in the distribution system leading to after growth, and incidences of high turbidity are some of the aesthetic and operational problems associated with iron in water supplies. Iron removal from groundwater is, therefore, a major concern for water supply companies using groundwater [3, 25]. Iron removal from groundwater is based on transforming soluble ferrous iron (Fe(II)) (by oxidation) into insoluble ferric iron (Fe(III)) compounds. Iron is oxidized with oxygen or other oxidants (potassium manganate (VII), ozone, chlorine), and with the use of ironoxidizing bacteria [1, 27]. In oxygen saturated water deprived of organic substances a quick oxidation of $\mathrm{Fe}^{2+}$ to $\mathrm{Fe}^{3+}$ takes place. The necessary time for $\mathrm{Fe}^{2+}$ ions oxidation extends mainly along with the concentration of $\mathrm{Fe}^{2+}$ and $\mathrm{H}^{+}$ in water, and to a smaller degree, with an increase of water temperature $[9,11]$. Gonczarow et al. [5] proved, that half times of oxidation reaction of $\mathrm{Fe}^{2+}$ to $\mathrm{Fe}^{3+}$, at oxygen partial pressure equal to $21.3 \mathrm{kPa}$, extended greatly along with an increasing concentration of hydrogen ions in treated water and for $\mathrm{pH}=7, \mathrm{pH}=6$ and $\mathrm{pH}=5$ amounted to approximately $4 \mathrm{~min}, 6 \mathrm{~h}$ and one month. In natural waters where organic substances are present, at the same $\mathrm{pH}$ values, $\mathrm{pO}_{2}$, concentration of $\mathrm{Fe}^{2+}$, the speed of iron oxidation is several times less, which, according to some researchers $[1,5,19,28]$ is caused by stabilization of $\mathrm{Fe}^{2+}$ by organic compounds. In the presence of organic substances, especially humic acids, the reaction of forming complexes with $\mathrm{Fe}^{2+}$ ions competes with oxidation of $\mathrm{Fe}^{2+}$ to $\mathrm{Fe}^{3+}$ and precipitation in a form of iron(III) hydroxide. Many researchers claim $[5,22]$ that the amount of complex bonded or oxidized $\mathrm{Fe}^{2+}$ depends on water $\mathrm{pH}$ and qualitative and quantitative composition of dissolved organic substances. Oxidation of the complexed $\mathrm{Fe}^{2+}$ goes very slowly along with formation of relevant $\mathrm{Fe}^{3+}$ complexes. Iron (III) formed as a result of this reaction can be reduced by organic compounds which depends on the stability of bindings in complex combinations. The speed of $\mathrm{Fe}^{2+}$ oxidation in the presence of organic substances is affected by the concentration of organic ligands and water $\mathrm{pH}$ and is the slowest with a high concentration of organic substances and $\mathrm{H}^{+}$ions in water. It is likely to be linked with, according to Nernst equation, with an increased oxidation-reduction potential of $\mathrm{Fe}^{3+} / \mathrm{Fe}^{2+}$ system [5]. As a result of aeration the easily sedimenting agglomerates of iron (III) hydroxide do not precipitate, instead, colloidal and water dissolved colour iron bonds with organic compounds are forming for the removal of which conventional groundwater treatment systems such as aeration, sedimentation and filtration are not sufficient $[6,13,14,15,16,23]$. Jobin and Ghosh and Theis and Singer 
$[3,9,10,29]$ found that many dissolved organic compounds were able to complex $\mathrm{Fe}(\mathrm{II})$, thereby rendering $\mathrm{O}_{2}$ (aq) ineffective for the oxidation of the reduced iron. In groundwater containing the humic substances, iron may occur in a form of relatively stable/durable complexes of various solubility and in a form of colloids, and the profile of the combinations formed depends on the type of the humic substances, $\mathrm{pH}$ value and a degree of oxidation of iron ions [5]. According to Van Dijk, Raschid and Trojanowski [11], the binding ability of the humic acids is bigger in relation to $\mathrm{Fe}^{2+}$ ions whereas Schnitzer and Skinner [25] state that $\mathrm{Fe}^{3+}$ ions are bound more strongly than $\mathrm{Fe}^{2+}[11,29]$. Several researchers $[5,6,22,29]$ suggest various mechanisms of binding iron by the humic acids. As Gonczarow et al. [5] as well as Pandey et al. [22] point out formation of chelate complexes with the humic acids in natural waters occurs as a result of an exchange reaction between hydrogen ions of carboxyl and phenol groups of the humic acids and iron cations existing under such conditions mainly in a form of hydroxo-complexes $[\mathrm{Fe}(\mathrm{OH})]^{2+},\left[\mathrm{Fe}(\mathrm{OH})_{2}\right]^{+}$, such chelate iron complexes are regarded as the most stable (Fig. 1).

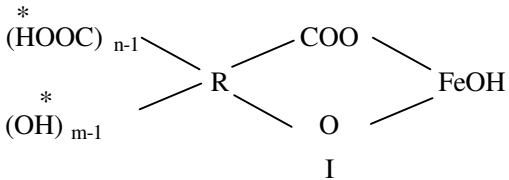

<smiles>O=C(O)C(C(=O)O)(C(=O)O)P([Hg]O)(C(=O)O)(C(=O)O)C(=O)O</smiles>

III

hydrogen ions able to exchange coordinate bond

Fig. 1. Structure of iron-humic complexes [5]

At $\mathrm{pH} \geq 8.0 \mathrm{H}^{+}$ions dissociate from hydroxyl groups whereas at $\mathrm{pH}=4.6-4.9$ dissociation of $\mathrm{H}^{+}$ions starts from carboxyl groups. According Narkis and Rebhun [29] at $\mathrm{pH} \geq 8.0$ humic substances are completely dissociated. Humic substance has many $\mathrm{COOH}$ and $\mathrm{Ar}-\mathrm{OH}$ groups, which can be partially ionized into the corresponding anions, $\mathrm{COO}^{-}$and $\mathrm{Ar}^{-} \mathrm{O}^{-}$, in water to afford a polyanioncharged molecule. It is inferable that a humic substance molecule having the functional groups and/or their ionized preferentially interacts with surface cationic sites $\left(\mathrm{Fe}^{3+}\right)$. According to numerous researchers $[5,6,12]$, one of the reasons for iron stabilisation by organic substances in groundwater may also be formation of the so called protective colloids of hydrophilic character as a result 
of adsorption of organic substances on iron(III) hydroxide surface. Summing up, the conclusion may be clear that presence of organic substances, and especially humic substances in groundwater significantly impedes removal of iron. Therefore, there have been several various attempts made in order to intensify removal of iron present in combinations with organic ligands. One of the recommended methods here is application of strong oxidizers. For this purpose, however, it is not advisable to use chlorine compounds due to the risk of forming chlorinated organic compounds, including THM [16, 21]. Furthermore, as Sawiniak found [24], using chlorine leads to formation of iron compounds of colloidal character which are not retained on deposits of rapid filters. The advisability of applying other oxidizers such as ozone, hydrogen peroxide is also questionable. According to Graham [23], the mechanism of ozone oxidation is based on transforming the structure of humic substances as a result of breaking heavy molecular weight particles into smaller ones which causes a damage of the conjugated system affecting the colour, but also causes formation of sideproducts of the ozonation process such as aldehydes, ketones and carboxyl acids $[7,8,18,21,30,32,32]$. Thus, oxidation efficiency is apparent, because colour reduction is not always in line with a release of iron ions from complexes and their oxidation as well as lowering of DOC concentration in treated water. Knocke [9] demonstrate that free chlorine, hydrogen peroxide and even ozone were ineffective for $\mathrm{Fe}(\mathrm{II})$ oxidation when the iron was complexed by certain samples of humic and fulvic acids. Molecular weight of the DOC had a key role in this regard. Higher molecular weight organic compounds more efficiently protected $\mathrm{Fe}$ (II) from the oxidant. Results of the research carried out by numerous researchers $[2,4,9,10,12,19,2024]$ showed that for oxidation of $\mathrm{Fe}^{2+}$ occurring in combinations with organic substances it is beneficial to apply potassium manganate (VII), because the oxidation process is additionally supported by sorption and catalytic properties of manganese (IV) oxide [19, 20]. Uncomplexed $\mathrm{Fe}(\mathrm{II})$ was oxidized almost instantaneously $(\mathrm{t}<1 \mathrm{~s})$ by the addition of potassium manganate (VII). However, the presence of significant amounts of humic or fulvic acids, resulting in a high degree of $\mathrm{Fe}$ (II) complexation, inhibited Fe(II) oxidation efficiency. Analysis of the results of the tests carried out on infiltration water of the Olawa river showed that the efficiency of removing humic substances increased along with the dose of potassium manganate (VII) and with an increase of iron concentration in untreated water [12]. The same finding was reported by Knocke, who thinks that the resulted manganese (IV) oxide acting as a weight and adsorbent improves sedimentation properties of iron(III) hydroxide and the related humic substances [10]. An advantage of potassium manganate (VII) as an oxidizer is also that it does not generate formation of oxidation side products having negative effects on human health [23]. The aim of the present study was to compare the 
efficiency of dissolved oxygen and potassium manganate (VII) for iron removal from the groundwater with an increased quantity of organic substances via oxidation and sedimentation processes.

\section{MATERIALS AND METHODS}

\subsection{Water samples}

The subject of research was groundwater from Quaternary formations characterized by a high concentration of total iron - amounting to 7.20 $\mathrm{mgFe} / \mathrm{dm}^{3}$, more intensive colour - up to $33 \mathrm{mgPt} / \mathrm{dm}^{3}$ and turbidity up to 25.0 NTU, and also a high quantity of organic substances (TOC from 5.50 to 7.50 $\mathrm{mgC} / \mathrm{dm}^{3}$ ) and manganese (up to $0.37 \mathrm{mgMn} / \mathrm{dm}^{3}$ ).

Table 1. Groundwater quality indicators

\begin{tabular}{|l|c|c|c|c|}
\hline \multirow{2}{*}{ Indicator } & \multirow{2}{*}{ Unit } & \multicolumn{3}{c|}{ Value } \\
\cline { 3 - 5 } & & Minimum & Average & Maximum \\
\hline $\mathrm{pH}$ & - & 7.00 & - & 7.14 \\
\hline Dissolved Oxygen & $\mathrm{mgO}_{2} / \mathrm{dm}^{3}$ & 0.50 & 0.55 & 0.60 \\
\hline Colour & $\mathrm{mgPt} / \mathrm{dm}^{3}$ & 19 & 28 & 33 \\
\hline Turbidity & $\mathrm{NTU}$ & 9.40 & 20.13 & 25.00 \\
\hline Iron total & $\mathrm{mgFe} / \mathrm{dm}^{3}$ & 5.47 & 6.10 & 7.20 \\
\hline Iron (II) & $\mathrm{mgFe} / \mathrm{dm}^{3}$ & 2.64 & 3.39 & 4.36 \\
\hline Iron(III) & $\mathrm{mgFe} / \mathrm{dm}^{3}$ & 1.11 & 2.70 & 4.13 \\
\hline Manganese & $\mathrm{mgMn} / \mathrm{dm}^{3}$ & 0.20 & 0.29 & 0.37 \\
\hline TOC & $\mathrm{mgC/ \textrm {dm } ^ { 3 }}$ & 5.50 & 6.00 & 7.50 \\
\hline TOC/Iron total (D) & - & 0.50 & 0.77 & 1.00 \\
\hline Fe(II)/Iron total (C) & $\%$ & 48.25 & 55.57 & 60.64 \\
\hline
\end{tabular}

Iron (II) and iron (III) compounds were present in the water. The concentration of dissolved oxygen changed within the range of 0.50 to $0.60 \mathrm{mgO} / \mathrm{dm}^{3}$, and the $\mathrm{pH}$ value within the range of 7.00 to 7.14 (Tab. 1). The water samples examined differed in terms of the value of the ratio of the TOC concentration and the concentration of total iron (D), the participation of the concentration of $\mathrm{Fe}$ (II) in the concentration of total iron (C), and its turbidity and intensity of colour indicated the presence of colloidal and dissolved combinations of iron with organic compounds.

\subsection{Experimental procedure}

In the research the effectiveness iron removal from the groundwater after aeration and chemical oxidisation was determined.

The effects of water treatment in technological systems were assessed: 
- oxidation of $\mathrm{Fe}(\mathrm{II})$ by dissolved oxygen and $2 \mathrm{~h}$ sedimentation, - oxidation of $\mathrm{Fe}(\mathrm{II})$ by potassium manganate (VII) and $2 \mathrm{~h}$ sedimentation.

The raw water was aerated with compressed air for a period of time of $15 \mathrm{~min}$, obtaining a dissolved oxygen concentration at a level of about $10 \mathrm{mgO}_{2} / \mathrm{dm}^{3}$, that is, about $100 \%$ water saturation with oxygen. Also, chemically pure solution of potassium manganate (VII) was used to oxidise the Fe(II) ions; the oxidisation time amounted to $5 \mathrm{~min}$, and the dose of oxidising agent was determined in view of the concentration of $\mathrm{Fe}(\mathrm{II})$ at an amount equal to $100 \%$ of the stoichiometric demand $\left(\mathrm{D}_{\text {stech }} \mathrm{KMnO}_{4}=2.50 \div 4.10 \mathrm{mgKMnO} / \mathrm{dm}^{3}\right)$.

\subsection{Analytical methods}

The physical-chemical composition of both the raw groundwater as well as treated water was determined according to the International Standard methods. The colour (according to Pt scale), total iron, iron (II) concentrations were determined with the Dr 3900 (HACH Lange) spectrophotometer. The colour was indicated in accordance with ISO 7887-Method C [33]. Quartz cuvette with path length of light $50 \mathrm{~mm}$ was used. It was determinated after filtration of the water sample through a membrane filter of pore size $0.45 \mu \mathrm{m}$. Colour of the sample was calculated using following equation: $\mathrm{C}=\mathrm{A}_{410} / \mathrm{ad}\left[\mathrm{mgPt} / \mathrm{dm}^{3}\right]$. Where $\mathrm{C}$ is true color of the sample, $\mathrm{A}_{410}$-absorbance of the sample at $\lambda=410 \mathrm{~nm}$, a specific absorption coefficient of the calibration solution of potassium hexachloroplatine and cobalt chloride $\left[\mathrm{mm}^{-1}\left(\mathrm{mgPt} / \mathrm{dm}^{3}\right)^{-1}\right]$, d-optical pathlength (mm) [33]. Iron (II) was measured using the 1,10 phenanthroline method. Total iron was measured using the same method except that a reducing reagent was also included in a reagent powder pillow to convert $\mathrm{Fe}(\mathrm{III})$ to $\mathrm{Fe}(\mathrm{II})$. The TOC was measured with a Shimadzu TOC analyzer. The $\mathrm{pH}$ of the raw water and the purified water was determined with an WTW Multi Line P4 with an combination $\mathrm{pH}$ electrode with temperature corrections. The dissolved oxygen of the raw water and the purified water was determined with an WTW Multi 3410 SET 4 with an optical oxygen sensor FDO ${ }^{\mathrm{R}} 925$ (Germany). Turbidity was measured using the Hach $2100 \mathrm{~N}$ Turbidimeter- the nephelometric method. Manganese concentrations were determined with the atomic absorption method (Analyst 700, Perkin Elmer Company, US).

\section{RESULTS AND DISCUSSION}

\subsection{Raw Water}

It has been shown that in the raw water samples turbidity correlated with the concentration of $\mathrm{Fe}(\mathrm{III})$ and the coefficient $\mathrm{D}$ (the value of the ratio of the TOC concentration and the concentration of total iron), and the intensity of colour 
with the concentration of total iron, Fe(III) and also the coefficient D. A linear dependence has also been found between the coefficients D and C (the

participation of the concentration of $\mathrm{Fe}(\mathrm{II})$ in the concentration of total iron). Equations of linear correlations between them, the values of the results of the Pearson correlation $(\mathrm{R})$ and the probability of the occurrence of the correlation (p) are presented in Table 2.

Table 2. Parameters of the linear correlations between the indices of the quality of the raw water samples under research

\begin{tabular}{|l|c|c|}
\hline \multicolumn{1}{|c|}{ Equation of linear correlation } & $\begin{array}{c}\text { Coefficient of the } \\
\text { Pearson } \\
\text { correlation }(\mathrm{R})\end{array}$ & $\begin{array}{c}\text { Probability of the occurrence } \\
\text { of the correlation }(\mathrm{p}) ; \%\end{array}$ \\
\hline Turbidity $=6.7985 \mathrm{Fe}(\mathrm{III})+2.1343$ & 0.652 & $\mathrm{n}=61 ; \mathrm{p}=99.95$ \\
\hline Turbidity $=37.698-15.312 \mathrm{D}$ & 0.642 & $\mathrm{n}=61 ; \mathrm{p}=99.95$ \\
\hline Colour $=3.0924 \mathrm{Fe} \mathrm{t}_{\text {tot }}+4.3833$ & 0.570 & $\mathrm{n}=61 ; \mathrm{p}=99.95$ \\
\hline Colour $=4.6621 \mathrm{Fe}(\mathrm{III})+10.469$ & 0.514 & $\mathrm{n}=61 ; \mathrm{p}=99.95$ \\
\hline Colour $=37.1820-18.231 \mathrm{D}$ & 0.666 & $\mathrm{n}=61 ; \mathrm{p}=99.95$ \\
\hline $\mathrm{C}=10.687 \mathrm{D}+38.942$ & 0.666 & $\mathrm{n}=61 ; \mathrm{p}=99.95$ \\
\hline
\end{tabular}

The values of the coefficients of the Pearson correlations indicate an important dependence between the indices of water pollution under research. It has been shown that as values of the coefficients determining the quantity of organic pollution related to the total iron concentration increased, the intensity of colour and turbidity of the water samples under research decreased, and as values of the ratio of the TOC concentrations and Fe total (D) increased the participation (\%) of $\mathrm{Fe}$ (II) ions in $\mathrm{Fe}$ total (C) increased, which confirms the importance of the influence of the occurrence and concentration of organic substances in decreasing the rate of oxidisation of $\mathrm{Fe}(\mathrm{II})$ to $\mathrm{Fe}(\mathrm{III})$.

\subsection{Oxidation of $\mathrm{Fe}(\mathrm{II})$ to $\mathrm{Fe}(\mathrm{III})$}

In order to oxidize $\mathrm{Fe}(\mathrm{II})$ to $\mathrm{Fe}(\mathrm{III})$ the groundwater samples were aerated or chemically pure solution of potassium manganate (VII) was used in a stoichiometric amount in comparison to the concentration of $\mathrm{Fe}(\mathrm{II})$. Regardless of the oxidizing agent which was used the oxidization rate was greater than $87 \%$. However, the difference in the time of the oxidization of $\mathrm{Fe}$ (II) during aeration and oxidization with potassium manganate (VII) was important. After aeration, a further increase in colour was observed in the water samples during two hours sedimentation in comparison to 15 minutes aeration, which meant that there was further oxidization of $\mathrm{Fe}(\mathrm{II})$ to $\mathrm{Fe}(\mathrm{III})$. This phenomenon was not observed when potassium manganate (VII) was used as an oxidizing agent. Potassium manganate (VII) caused a decrease in the colour of 
the water, and also a less increase in the turbidity of the water in comparison to the water samples after aeration (Tab.3). According to Ficek [4] potassium manganate (VII) reacts rapidly with iron (II) also in the presence of organic substances and it is a versatile oxidant that will react with organic compounds easily breaking carbon-carbon double bonds and oxidizing functional groups that are responsible for many problems in drinking water such as colour and taste.

Table 3. Influence of the kind of oxidizing agent on the average unit change in colour $(\Delta \mathrm{B} / \Delta \mathrm{Fe}(\mathrm{III}))$ and turbidity $(\Delta \mathrm{M} / \Delta \mathrm{Fe}(\mathrm{III}))$ of the water samples

\begin{tabular}{|l|c|c|}
\hline Type of oxidant & $\Delta \mathrm{M} / \Delta \mathrm{Fe}(\mathrm{III})$ & $\Delta \mathrm{B} / \Delta \mathrm{Fe}(\mathrm{III})$ \\
\hline Dissolved Oxygen & 6.50 & 5.90 \\
\hline $\mathrm{KMnO}_{4}$ & 1.30 & -2.70 \\
\hline
\end{tabular}

Some researchers have expressed an opinion that utilization of a strong oxidizing agent to break the organic molecules, thus reducing the colour, can also make the organic substance much less tenacious as a complexing agent [18]. The rate of oxidisation of Fe(II) during aeration was determined by the value of the coefficient of co-occurrence of TOC and total iron in raw water (D). As it increased the effectiveness of the oxidisation of Fe(II) with oxygen dissolved in the water decreased, which was especially clear in the case of the water samples which differed in the value of the coefficient D - Fig. 2.

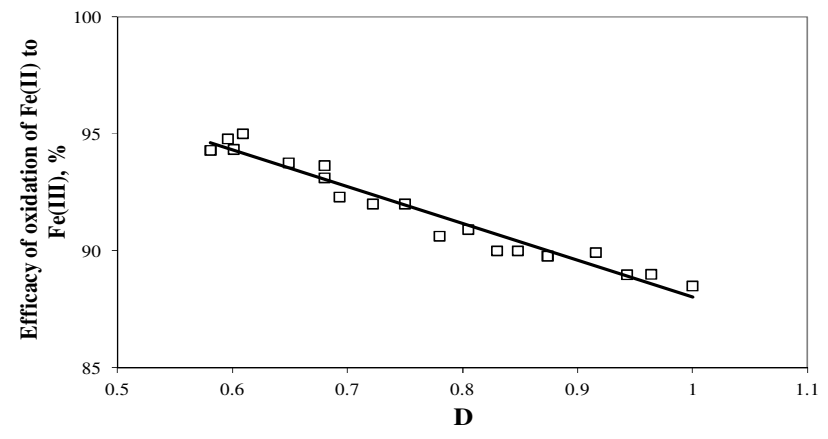

Fig. 2. Effect of coexistence ratio of TOC concentration and concentration of total iron (D) on efficacy in oxidising $\mathrm{Fe}(\mathrm{II})$ to $\mathrm{Fe}(\mathrm{III})$ (aeration)

The equations of the linear correlations between the coefficient $\mathrm{D}$ and the values of the colour and turbidity in the water after aeration are presented in table 4 . The colour intensity and turbidity of aerated water also decreased with the increasing the value of the coefficient $\mathrm{D}$. On the basis of equations of linear correlations presented in Table 4, it can also be stated that colour intensity and turbidity of aerated water increased with increasing Fe (III) concentration. In the 
water samples in which potassium manganate (VII) was used to oxidize $\mathrm{Fe}(\mathrm{II})$ a dependence between the value of the ratio of coexistence of organic substances and iron total and the rate of oxidization of $\mathrm{Fe}$ (II) to $\mathrm{Fe}$ (III) was not observed.

Table 4. Parameters of linear correlations between the coefficient $\mathrm{D}$ and the indices of the quality of the water samples after aeration $\left(t_{a}=15 \mathrm{~min}\right.$.)

\begin{tabular}{|l|l|l|}
\hline \multicolumn{1}{|c|}{ Equation of linear correlation } & $\begin{array}{c}\text { Coefficient of } \\
\text { the Pearson } \\
\text { correlation }(\mathrm{R})\end{array}$ & \multicolumn{1}{|c|}{$\begin{array}{c}\text { Probability of the } \\
\text { occurrence of the } \\
\text { correlation }(\mathrm{p}) ; \%\end{array}$} \\
\hline Colour $=32.922-7.2643 \mathrm{D}$ & 0.600 & $\mathrm{n}=25 ; \mathrm{p}=98.40 \%$ \\
\hline Colour $=7.8806 \mathrm{Fe}(\mathrm{III})-6.1811$ & 0.729 & $\mathrm{n}=25 ; \mathrm{p}=99.95 \%$ \\
\hline Turbidity $=70.302-33.267 \mathrm{D}$ & 0.597 & $\mathrm{n}=25 ; \mathrm{p}=98.20 \%$ \\
\hline Turbidity $=3.8748 \mathrm{Fe}(\mathrm{III})+18.05$ & 0.729 & $\mathrm{n}=25 ; \mathrm{p}=99.95 \%$ \\
\hline
\end{tabular}

Comparison of $\mathrm{Fe}$ (II) oxidation efficiency in water samples with the same value of coefficient of co-occurrence of organic matter and total iron $(\mathrm{D}=1.00)$ showed slightly higher oxidation efficiency with with the use of potassium manganate (VII) $(96 \%)$ than 15 min of aeration (88\%).

\subsection{Effectiveness of removing iron in the process of sedimentation}

Despite great efficiency in oxidizing $\mathrm{Fe}(\mathrm{II})$ to $\mathrm{Fe}(\mathrm{III})$ with dissolved oxygen and potassium (VII) manganate, the two hour sedimentation did not ensure adequate removal of iron from water. Oxidation products were finely dispersed, whereas after sedimentation iron compounds (III) remained first of all.

Table 5. Water quality characteristics after Fe(II) oxidation and sedimentation

\begin{tabular}{|l|c|c|}
\hline \multirow{2}{*}{ Indicator, Unit } & \multicolumn{2}{|c|}{ Type of oxidant } \\
\cline { 2 - 3 } & $\mathrm{O}_{2}$ & $\mathrm{KMnO}_{4}$ \\
\hline $\mathrm{pH},-$ & $8.00 \div 8.16$ & $7.05 \div 7.17$ \\
\hline Colour, $\mathrm{mgPt} / \mathrm{dm}^{3}$ & $20 \div 87$ & $4 \div 12$ \\
\hline Turbidity, $\mathrm{NTU}$ & $17.8 \div 46.0$ & $1.4 \div 23.0$ \\
\hline Iron total, $\mathrm{mgFe} / \mathrm{dm}^{3}$ & $3.00 \div 5.50$ & $0.50 \div 3.42$ \\
\hline Iron (II), $\mathrm{mgFe} / \mathrm{dm}^{3}$ & $0.01 \div 0.30$ & $0.09 \div 0.25$ \\
\hline Iron(III), $\mathrm{mgFe} / \mathrm{dm}^{3}$ & $2.25 \div 4.64$ & $0.41 \div 3.23$ \\
\hline Manganese, $\mathrm{mgMn} / \mathrm{dm}^{3}$ & $0.23 \div 0.34$ & $0.16 \div 0.19$ \\
\hline TOC, $\mathrm{mgC} / \mathrm{dm}^{3}$ & $5.20 \div 7.50$ & $3.23 \div 4.20$ \\
\hline
\end{tabular}

The experiment results presented in Tables 1 and 5 lead to the conclusion, that all water samples after aeration and sedimentation were characterized by a greater colour intensity and turbidity than the water raw. In the majority of water samples, after undergoing aeration and sedimentation, no changes in the content of organic pollutants were found (in the other samples the changes were 
minimum), which indicates that only inorganic iron compounds (III) sedimented. On then hand, invulnerable to sedimentation colourful finely dispersed compounds of $\mathrm{Fe}$ (III) stabilized by organic compounds were left in water. The experiment results presented in Table 6 also show that the dissolved organic compounds (approximately 74\%) that remained in the filtrate was formed by water soluble fractions and iron compounds, (mainly $\mathrm{Fe}(\mathrm{III})$ ) occurred in the aerated water in a form of colloids and hardly sedimenting particles.

Table 6. Effect of the filtration on efficacy of pollutants removal from groundwater after aeration and sedimentation

\begin{tabular}{|l|c|c|c|c|}
\hline \multirow{2}{*}{ Indicator, Unit } & \multirow{2}{*}{$\begin{array}{c}\text { Raw } \\
\text { water }\end{array}$} & \multicolumn{3}{|c|}{ Water after aeration, sedimentation and filtration } \\
& & $\begin{array}{c}\text { Soft filter } \\
\text { baper }\end{array}$ & $\begin{array}{c}\text { Hard filter } \\
\text { paper }\end{array}$ & $\begin{array}{c}\text { Filter paper } \\
0.45 \mu \mathrm{m}\end{array}$ \\
\cline { 3 - 5 } & 27 & 37 & 15 & 5 \\
\hline Colour, $\mathrm{mgPt} / \mathrm{dm}^{3}$ & 19.10 & 9.50 & 3.70 & 0.07 \\
\hline Turbidity, $\mathrm{NTU}$ & 5.83 & 1.65 & 0.60 & 0.12 \\
\hline Iron total, $\mathrm{mgFe} / \mathrm{dm}^{3}$ & 2.38 & 1.50 & 0.50 & 0.06 \\
\hline Iron $(\mathrm{III}), \mathrm{mgFe} / \mathrm{dm}^{3}$ & 3.45 & 0.15 & 0.10 & 0.06 \\
\hline Iron $(\mathrm{II}), \mathrm{mgFe} / \mathrm{dm}^{3}$ & 5.50 & 5.40 & 5.00 & 4.00 \\
\hline TOC, $\mathrm{mgC} / \mathrm{dm}^{3}$ & & & & \\
\hline
\end{tabular}

It was found, that after oxidation by potassium manganate (VII) and sedimentation the colour intensity and turbidity of water samples decreased. Furthermore, after potassium manganate (VII) oxidation, the efficiency of removing iron and manganese compounds and organic substances presented in water samples was greater than after aeration (Table 1 and 5). The greater water treatment efficiency after applying potassium manganate (VII) was probably caused by the precipitating manganese oxide (IV). This proves reports in literature $[9,16]$, that in neutral environment, or close to it, which is the usual property of natural waters, in order to oxidize Fe(II) ions occurring in compounds with organic substances, it is beneficial to use potassium manganate (VII), because a reaction product, apart from iron(III) hydroxide, is manganese oxide (IV) which, acting as a weight and adsorbent, improves sedimenting qualities of ferro-organic agglomerates. Applying potassium manganate (VII) was also beneficial due to the fact, that $\mathrm{pH}$ of the treated water did not increase ( $\mathrm{pH}$ of raw water: 7.00-7.14; $\mathrm{pH}$ after oxidation $\mathrm{KMnO}_{4}$ : 7.05-7.17; $\mathrm{pH}$ after aeration: 8.00-8.16 - Tables 1 and 5). Narkis and Rebhun [27] state, that in case of organic substances, such as, for example, humic substances, at water $\mathrm{H}=4$.64.9 dissociation of $\mathrm{H}^{+}$ions from carboxyl groups starts $(-\mathrm{COOH})$, and at $\mathrm{pH} \geq 8$ $\mathrm{H}^{+}$ions dissociate from hydroxyl groups $(-\mathrm{OH})$ and these substances are completely dissociated. According to Świderska-Bróż [26], an increase in the 
degree of dissociation of humic substances leads to a decrease in the efficiency of removal of heavy metals from water as a result of formation of colloidal and dissolved metal-organic compounds. In case of groundwater, coloured chelating iron complexes with organic substances, especially with humic matter, can form. This can be confirmed by the results of the research carried out by the author of the present paper, where in water samples after oxidation and $2 \mathrm{~h}$ sedimentation and only after applying dissolved oxygen as an oxidizer causing an increase of $\mathrm{pH}$ to $\geq 8$, it was found, that water colour intensity increased (up to approximately $60 \%$ ), the efficiency in removing iron compounds grew by $43 \%$ on the maximum (for the lowest value of the ratio $\mathrm{D}=0.50$ ), whereas the removal of organic substances proved to be inefficient (Table 1 and 5). The analysis of the experiment results also showed that the effect of $\mathrm{D}$ value on the efficiency of removing total iron was significant only when aeration was applied. Along with an increase of the quotient $\mathrm{TOC} / \mathrm{Fe}_{\text {tot }}$, the efficiency of removing iron compounds from water after aeration in the sedimentation process decreased (Fig. 3).



Fig. 3. Effect of coexistence ratio (D) on efficacy of total iron removal from water (aeration and sedimentation)

The regularity found confirms the literature reports [5], that an increase in organic ligand amount in the raw water leads to an increase of the durability of ferro-organic compounds as well as of the content of dissolved coloured ferroorganic complexes difficult to remove in sedimentation process. In water samples after oxidation with potassium manganate (VII) and sedimentation the efficiency of removing total iron was greater than the one reached when oxidizing with dissolved oxygen (Table 5), however, it did not correlate with the values of the coefficient of organic compound and total iron (D) co-occurrence in raw water. Comparison the efficiency in removing total iron from water samples with the same $D$ value $(D=1.00)$ confirmed a greater efficiency in removing total iron from water containing doses of potassium manganate (VII), however it did not guarantee an adequate elimination of iron compounds, the 
content of which after sedimentation was $0.55 \mathrm{mgFe} / \mathrm{dm}^{3}$ (after $\mathrm{KMnO}_{4}$ oxidation) and $2.40 \mathrm{mgFe} / \mathrm{dm}^{3}$ (after aeration).

\section{CONCLUSIONS}

The test results analysis leads to the following conclusions:

1. The percentage of $\mathrm{Fe}(\mathrm{II})$ ions in the overall contents of total iron (C) increased along with an increase of the quotient of organic substance concentration to total iron in raw water, whereas the colour intensity and turbidity decreased, which proves the importance of the impact that the presence and concentration of organic substances have on hindering the oxidation process of $\mathrm{Fe}$ (II) to $\mathrm{Fe}(\mathrm{III})$.

2. The increasing value of the coefficient of organic substance and total iron co-occurrence in raw water (D) led to a decrease in the efficiency of oxidation of $\mathrm{Fe}$ (II) to $\mathrm{Fe}(\mathrm{III})$ with dissolved oxygen. This regularity was not found when applying the chemical oxidizer, potassium managanate (VII), which, contrary to dissolved oxygen, lessened water colour intensity and caused a smaller increase in water turbidity.

3. A greater efficiency in removing iron compounds in oxidation and sedimentation processes was achieved when applying potassium manganate (VII) as an oxidizer, because one of the oxidation products was manganese oxide (IV) precipitating from water, which, acting as a weight and adsorbent, improved sedimenting properties of the ferro-organic agglomerates formed.

4. Application of potassium manganate (VII) as an oxidizer, as compared with dissolved oxygen, was also beneficial because in the treated water $\mathrm{pH}$ did not grow. As a result of aeration the $\mathrm{pH}$ value of the treated water reached $\geq 8$ which may have caused a complete dissociation of organic substances, and at the same time may have created conditions for forming of colourful hardly sedimenting ferro-organic combinations.

5. The amount of total iron removed from water as a result of oxidation and sedimentation, only after water aeration, decreased along with an increase in the value of the coefficient of organic substance and total iron co-occurrence in raw water (D), because, as it is reported, durability constant of a metalorganic complex increases along not only with an increase of $\mathrm{pH}$, but also along with an increase in the amount of organic ligands in a metal-organic complex.

6. Studies involving Fe(II) and TOC indicated that complexed iron was very difficult to remove by the oxidation and subsequent precipitation of iron(III) hydroxide. Efficient removal of complexed iron must rely on processes that can remove the organic matter, such as coagulation. 


\section{REFERENCES}

1. Albrektiene R., Rimeika M., Lubyte E.: The removal of iron-organic complexes from drinking water using coagulation process, The 8 th International Conference May 19-20, Vilnius, Lithuania 2011.

2. Ciupa R., Dzienis L.: Zastosowanie $\mathrm{KMnO}_{4}$ i $\mathrm{ClO}_{2}$ do usuwania organicznych form żelaza $i$ manganu $z$ wód podziemnych, Ochrona Środowiska, 1/60 (1996) 25-26.

3. Civardi J., Tompeck M.: Iron and manganese removal handbook. Second Edition. Denver, CO: American Water Works Association 2015.

4. Ficek K., Vella P.: Potasium permanganate the oxidation solution to many water treatment problems, Zaopatrzenie w Wodę Miast i Wsi, Jakość i Ochrona Wód, Kraków 2000, 673-684.

5. Gonczarow T.O., Kołosow I. W., Kaplin W.: O formach nachorzdjenija metallow w powjerchnostnych wodach, Gidrometeoizdat, 77 (1982) 73-89.

6. Grabińska-Łoniewska A.: Biologiczne przemiany żelaza $i$ manganu $w$ środowisku oraz urządzeniach wodociagowych i ciepłowniczych. Wyd. Polskie Zrzeszenie Inżynierów i Techników Sanitarnych, Warszawa 2000.

7. Kabsch-Korbutowicz M., Urbanowska A.:Comparison of polymeric and ceramic ultrafiltration membranes for separation of natural organic matter from water, Environment Protection Engineering, 36 (2010) 125-135.

8. Kalkowska I., Giemza B., Nawrocki J.: Powstawanie aldehydów w procesie ozonowania wody, Ochrona Środowiska, 4/59 (1995) 37-39.

9. Knocke W.R., Van Benschoten J. E., Kearney M.J., Soborski A.W., Reckhow D. A.: Kinetics of manganese and iron oxidation by potassium permanganate and chlorine dioxide, JAWWA, 6 (1991) 80-87.

10. Knocke W.R., Shorney H.L., Bellamy J.D.: Examining the reactions between soluble iron. DOC and alternative oxidants during conventional treatment, JAWWA, 1 (1994) 117-127.

11. Kowal A. L., Świderska-Bróż M.: Oczyszczanie wody, PWN, WarszawaWrocław 2009.

12. Kowalski T.: Proces utleniania $w$ technologii oczyszczania wody, Ochrona Środowiska, 3/50(1993) 33-36.

13. Krupińska I., Świderska-Bróż M.: Effect of the presence of organic substances on the extent of iron compound removal from water via oxidation and sedimentation processes, Ochrona Środowiska, 30(2008) 3-7.

14. Krupińska I.: Suitability of Coagulation for Treatment of Groundwater, Rocznik Ochrona Środowiska, 14 (2012) 491-501.

15. Krupińska I.: Effect of Temperature and $\mathrm{pH}$ on the Effectiveness of Pollutant Removal from Groundwater in the Process of Coagulation, Ochrona Środowiska, 37(2015) 35-42. 
16. Krupińska I.: The impact of the oxidising agent type and coagulant type on the effectiveness of coagulation in the removal of pollutants from underground water with an increased content of organic substances, Journal of Environmental Engineering and Landscape Management, 24 (2016) 70-78.

17. Macioszczyk A., Dobrzyński D.: Hydrogeochemia strefy aktywnej wód podziemnych, PWN, Warszawa 2002.

18. Munter R., Overbeck P., Sutt J.: Which is the Best Oxidant for Complexed Iron Removal from Groundwater: The Kogalym Case, Ozone: Science and Engineering, 30 (2008) 73-80.

19. Nawrocki J., Biłozor S., Kalkowska I.: Uboczne produkty utleniania domieszek wód, Ochrona Środowiska, 3/50 (1993) 37-40.

20. Nawrocki J., Biłozor S.: Uzdatnianie wody, procesy chemiczne i biologiczne, Wyd. Nauk. PWN, Warszawa-Poznań 2010.

21. Nowacka A., Włodarczyk-Makuła M., Macherzyński B.: Comparison of effectiveness of coagulation with aluminum sulfate and pre-hydrolyzed aluminum coagulants, Desalination and Water Treatment, 52 (2014) 38433851.

22. Pandey A. K., Pandey S. D., Mstra V.: Stability constants of metal-humic acid complexes and its role in environmental detoxification, Ecotoxicology and Environmental Safety, 47(2000)195-200.

23. Perchuć M.: Wspótudziat żelaza i kwasów humusowych $w$ kształtowaniu sposobu uzdatniania barwnych wód podziemnych, Oficyna Wydawnicza Politechniki Warszawskiej, Warszawa 2004.

24. Sawiniak W.: Badania nad zastosowaniem wodorotlenku żelazowego do usuwania dużych ilości żelaza i manganu z wód podziemnych, Zeszyty Naukowe Politechniki Śląskiej, Gliwice 1990.

25. Schnitzer M., Skinner S. I. M.: Organo-metallic interactions in soils. Stability constants of $\mathrm{Cu}^{2+}, \mathrm{Fe}^{2+}$ and $\mathrm{Zn}^{2+}$ fullvic acids complexes. Soil Science 102 (1966) 102-361.

26. Sharma, S.K.: Adsorptive Iron Removal from Groundwater, Swets \& Zeitlinger B.V, Lisse, The Netherlands 2001.

27. Skoczko I., Piekutin J., Roszczenko A.: Usuwanie z wody związków żelaza i manganu metoda filtracji na wybranych złożach, Rocznik Ochrona Środowiska, 17(2015) 1587-1608.

28. Świderska-Bróż M.: Usuwanie organicznych połaczeń żelaza $z$ wód podziemnych, GWiTS, 1(1991) 18-21.

29. Świderska-Bróż M.: Interakcja związków humusowych $z$ wybranymi metalami ciężkimi oraz jej wptyw na usuwanie badanych metali $z$ wody.Wydawnictwo Politechniki Wrocławskiej. Wrocław 1985. 
30. Urbanowska A., Kabsch-Korbutowicz M.: Influence of operating conditions on performance of ceramic membrane used for water treatment, Chemical Papers, 68(2014) 190-196.

31. Urbanowska A., Kabsch-Korbutowicz M.: Characteristics of natural organic matter removed from water along with its treatment, Environment Protection Engineering, 42(2016) 183-195.

32. Urbanowska A., Kabsch-Korbutowicz M.: The properties of NOM particles removed from water in ultrafiltration, ion exchange and integrated processes, Desalination and Water Treatment, 57(2016) 13453-13461.

33. Water quality-Examination and determination of colour. International standard ISO 7887, 2011.

\section{WPEYW SUBSTANCJI ORGANICZNYCH NA SKUTECZNOŚĆ UTLENIANIA Fe(II) do Fe(III) ORAZ USUWANIA ZWIAZKKÓW ŻELAZA Z WODY PODZIEMNEJ W PROCESIE SEDYMENTACJI}

\section{Streszczenie}

Przedmiotem badań była woda podziemna charakteryzująca się wysokim stężeniem żelaza ogólnego do $7,20 \mathrm{mgFe} / \mathrm{dm}^{3}$ oraz podwyższoną zawartością substancji organicznych (OWO od 5,50 do $7,50 \mathrm{mgC} / \mathrm{dm}^{3}$ ). Badane próbki wody różniły się wartością ilorazu stężenia OWO do stężenia żelaza ogólnego (D), udziałem stężenia $\mathrm{Fe}(\mathrm{II})$ w stężeniu $\mathrm{Fe}_{\mathrm{og}}(\mathrm{C})$, a jej mętność i intensywność barwy wskazywały na obecność koloidalnych oraz rozpuszczonych połączeń żelaza ze związkami organicznymi. Celem badań było określenie wpływu stężenia substancji organicznych w wodzie podziemnej na skuteczność utleniania $\mathrm{Fe}$ (II) do $\mathrm{Fe}$ (III) tlenem rozpuszczonym w wodzie lub manganianem (VII) potasu, a także na skuteczność usuwania związków żelaza w procesie sedymentacji. Wykazano, że wraz ze wzrostem wartości współczynnika współwystępowania substancji organicznych i żelaza ogólnego w wodzie surowej (D) zmniejszała się skuteczność utleniania $\mathrm{Fe}(\mathrm{II})$ do $\mathrm{Fe}(\mathrm{III})$ tlenem rozpuszczonym. W próbkach wody, w których do utleniania Fe(II) stosowano manganian (VII) potasu nie stwierdzono wpływu wartości współczynnika D na skuteczność utlenienia Fe(II) do $\mathrm{Fe}(\mathrm{III})$. Zastosowanie manganianu (VII) potasu jako utleniacza zapewniło większą skuteczność usuwania związków żelaza z wody podziemnej w procesie sedymentacji niż napowietrzanie.

Słowa kluczowe: oczyszczanie wód podziemnych, substancje organiczne, napowietrzanie, manganian (VII) potasu, utlenianie $\mathrm{Fe}(\mathrm{II})$, usuwanie żelaza

Editor received the manuscript. 01.09.2017 